УДК 378.011.3-051:339.138

DOI https://doi.org/10.24919/2308-4863.1/27.203441

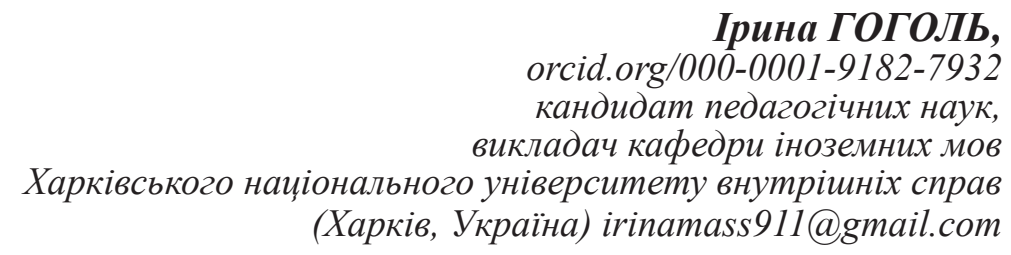

Валентина КОЧИНА, orcid.org/0000-0001-8031-4269 кандидат педагогічних наук, викладач кафедри іноземних мов

Харківського начіонального університету внутрішніх справ (Харків, Україна) depart10@ukr.net

\title{
РОЗВИТОК КОМУНІКАТИВНОЇ КОМПЕТЕНТНОСТІ МАЙБУТНІХ МАРКЕТОЛОГІВ У ПРОЦЕСІ ФАХОВОӤ ПІДГОТОВКИ
}

У статті розглядається питання розвитку комунікативної компетентності майбутніх маркетологів у процесі фахової підготовки, розкривається сутність поняття «комунікативна компетентність» фахівия, визначаються компоненти, які входять до ї̈ структури (операційно-діяльнісний, когнітивний, мотиваційно-иіннісний). Наголошується, щь вміння спілкуватися з партнерами, підлеглими й керівництвом - основа діяльності сучасного маркетолога. На основі аналізу психолого-педагогічної літератури авторки виділяють такі функиії професійного спілкування: регулятивну (координація офіційних стосунків під час професійній діяльності); комунікативну (відбувається інформаційний обмін); інтерактивну (здійснюється обмін діями); периептивну та рефлективну (взаємне сприйняття й налагодження взаєморозуміння між комунікантами). На основі аналізу наукових робіт у галузі професійної освіти економістів $і$ змісту освітньо-професійної програми підготовки бакалавра за спеиіальністю «Маркетинг» у статті виокремлюється сукупність комунікативних умінь, які є необхідними для формування комунікативної компетентності майбутнього маркетолога.

Зроблено висновки, що в основі професійної діяльності маркетолога лежить професійне спілкування, яке є невіддільним і важливим складником маркетингу. Підготовка фахівців з маркетингу значною мірою має економічний характер, спрямована на вивчення різних аспектів організації виробнищтва, збуту товарів і послуг, підвищення попиту покупців, проте формуванню навичок професійного спілкування, розвитку в студентів умінь здійснювати ефективну комунікацію не приділяють належної уваги у вищих навчальних закладах. Виконання перелічених функцій маркетингових комунікацій свідчить про те, що маркетолог повинен володіти значним обсягом знань, умінь $і$ навичок, пов 'язаних із професійною комунікацією, щубб вирішувати такий широкий спектр професійних завдань. Володіння комунікативними вміннями та навичками значною мірою визначає ефективність професійної діяльності маркетолога.

Ключові слова: комунікативна компетенція, маркетолог, фахова підготовка, комунікативні вміння, професійне спілкування.

Iryna GOGOL, orcid.org/000-0001-9182-7932 Candidate of Pedagogical Sciences, Teacher at the Department of Foreign Languages of Kharkiv National University of Internal Affairs

(Kharkiv, Ukraine) irinamass911@gmail.com

Valentyna KOCHYNA, orcid.org/0000-0001-8031-4269

Candidate of Pedagogical Sciences, Teacher at the Department of Foreign Languages of Kharkiv National University of Internal Affairs

(Kharkiv, Ukraine) depart10@ukr.net

\section{DEVELOPING COMMUNICATIVE COMPETENCE OF FUTURE MARKETERS IN THE PROCESS OF VOCATIONAL TRAINING}

The article deals with the question of communicative competence development of future marketers in the process of vocational training, the essence of the concept 'communicative competence' of a specialist has been revealed, the components, included in its structure (cognitive, operation-activity, motive - axiological) have been defined. It is noted 
that the ability to communicate with partners, employees and leadership is the basis of modern marketer's activity. On the basis of the psychology and pedagogical literature analysis, the author allocates the following functions of professional interaction: regulation (coordination of formal relationship in the process of professional activity); communicative (information exchange); interactive (ideas exchange); perceptual and reflective (mutual perception and understanding between communicators). On the basis of the analysis of scientific works in the field of economics education and the contents of the professional activity of the marketer, the combination of communicative skills, necessary for communicative competence development of future marketers is highlighted in the article.

The conclusions of the study were that the basis of marketer's professional activity is professional communication, which is important and integral part of marketing. It is established that in the implementation of marketing communications specialists perform the following functions: informative, persuasive, reminding, forming the image of the enterprise and the product, encouraging, interactive, research. Solving such a wide range of professional tasks and the implementation of these functions requires the marketer not only to possess a significant amount of knowledge, but, first of all, communicative skills, forming the basis of the professional communication development and largely determine the effectiveness of his professional activities.

Key words: communicative competence, marketer, vocational training, communicative skills, professional interaction.

Постановка проблеми. Сьогодні політична, соціально-економічна ситуація в Україні вимагає від майбутнього фахівця швидкої реакції на зміни й здатності до гнучкої орієнтації та адаптації в професійній сфері діяльності, що зумовлює особливу якість його фахової підготовки. Проте керівники підприємств стикаються з проблемою неефективності діяльності нових співробітників. Причиною цього дуже часто $\epsilon$ несформованість у працівника комунікативної компетентності як однієї з базових характеристик професійної компетентності та професійної підготовки загалом. Володіння комунікативною компетентністю необхідно кожному фахівцю, особливо якщо його професійна діяльність вимагає вміння встановлювати контакти, спілкуватися в соціумі, працювати 3 потоками інформації. Високий рівень сформованості комунікативної компетентності відкриває широкий спектр можливостей: взаємодіяти з багатьма людьми - носіями різної інформації, значно скорочувати шлях самостійного пошуку потрібних знань і часу, що витрачається на підбір необхідних джерел і їх обробку, змінювати характер осмислення отримуваної інформації, співвідносити іiї безпосередньо з вирішенням професійних завдань, тобто в процесі продуктивної комунікації значно швидше відбувається обмін актуальною інформацією, новими знаннями порівняно 3 довгою та кропіткою самостійною роботою поза комунікації.

У зв'язку з цим актуальною $є$ проблема підготовки конкурентоспроможних фахівців маркетингової галузі, які не лише володіють фаховими економічними знаннями, а й здатні орієнтуватися в умовах професійного спілкування, мають розвинуті професійно важливі якості, які їм потрібні, щоб стати успішним професіоналом. Це зумовлює важливість розроблення сучасних підходів до побудови процесу фахової підготовки майбутніх маркетологів, які базуються на визнанні необхідності професійної взаємодії, де пріоритетними є категорії «комунікація», «співробітництво», «взаєморозуміння». В Україні підготовку студентів-маркетологів здійснюють понад 100 закладів вищої освіти. Професійна підготовка маркетологів у закладах вищої освіти орієнтована переважно на опановування студентами фундаментальними спеціальними та професійними знаннями в галузі економіки, проте формуванню комунікативної компетентності, яка певною мірою визначає ефективність професійної діяльності маркетолога, на жаль, не приділяють значної уваги.

Аналіз досліджень. Значна кількість проведених досліджень ученими в галузі психології, етики, лінгвістики, педагогіки висвітлює проблематику культури спілкування як важливого чинника професіоналізму та майстерності фахівців (О. Баєва, I. Зарецька, Ф. Кузін, А. Панфілова, Г. Сагач та інші), питаннями формування професійної компетентності фахівців займалися Н. Бібік, В. Бондарь, Є. Зеєр, І. Зимня, Н. Кузьміна, А. Маркова, А. Хуторський та інші. Провідні вітчизняні вчені, які розглядають теоретичні і практичні аспекти професійної підготовки студентів економічних спеціальностей, зокрема майбутніх маркетологів, до ділового спілкування, - П. Бавіна, Н. Волкова, І. Горбуліч, В. Квартальнова, М. Макаренко, I. Ромащенко, Ю. Ситникова, Т. Шепеленко й інші.

Відзначаючи беззаперечну значущість здобутків теоретичних і практичних робіт, зауважимо, що попит на професію маркетолога в сучасній економічній сфері актуалізує проблему професійної підготовки цих фахівців, зокрема такий ії напрям, як формування комунікативної компетентності. Доцільність розв'язання зазначеної проблеми пов'язана $з$ необхідністю подолання суперечностей між потребами економічної галузі у фахівцях маркетингової сфери, здатних до ефективного розв'язання професійних завдань, і недостатньою визначеністю вимог до змісту підготовки майбутніх маркетологів; потребою у високопрофесійних кадрах, які здатні досягати високого економічного 
результату в професійній діяльності, і недостатньою їх підготовленістю до ефективного професійного спілкування; необхідністю формування комунікативної компетентності в студентів як майбутніх маркетологів і недостатньою розробленістю теоретичних, методичних засад і педагогічних умов іiї формування в процесі фахової підготовки в закладах вищої освіти.

Метою статті $є$ дослідження питання розвитку комунікативної компетентності майбутніх маркетологів у процесі фахової підготовки, виокремлення сукупності комунікативних умінь, які $€$ необхідними для формування комунікативної компетентності майбутнього маркетолога.

Виклад основного матеріалу. У період економічних перетворень Україна потребує висококваліфікованих економістів, спроможних ефективно працювати як у вітчизняній, так і в міжнародній економіці. Інтеграція до світової економічної спільноти призводить до змін у кваліфікаційних вимогах, що висуваються до сучасного маркетолога, зокрема це здатність до ефективної комунікації в професійній діяльності, здатність працювати в команді, спілкуватися 3 представниками інших професійних груп різного рівня - виробниками, постачальниками, споживачами (організаціями та особами), продавцями, керівниками (організацій, відділів), торговим персоналом, посередниками, конкурентами тощо, $з$ експертами й фахівцями 3 інших видів економічної діяльності, яка вимагає взаємодії з метою вирішення спільного завдання.

Уміння спілкуватися з партнерами, підлеглими й керівництвом - основа діяльності сучасного маркетолога. В. Кузін визначає професійну комунікацію (Кузин, 2002: 320) як складний процес розвитку та формування контактів, що заснований на необхідності в спільній діяльності. Професійне спілкування охоплює такі функції: регулятивну (координує офіційні стосунки під час професійній діяльності); комунікативну (відбувається інформаційний обмін); інтерактивну (здійснюється обмін діями); перцептивну та рефлективну (взаємне сприйняття й налагодження взаєморозуміння між комунікантами).

Комунікативна компетентність фахівця вважається найбільш важливою професійною компетенцією, оскільки розвиток комунікативної компетентності пов'язаний із формуванням у фахівця основних функціональних компетенцій, які розвивають творче мислення майбутнього фахівця, що дають йому змогу вирішувати низку конкретних практичних професійних завдань (Емельянов, 1985: 165). Важливими комунікативними компетенціями визначаються вміння розуміти й окреслювати психологічний зміст професійних обов'язків, усвідомлювати значущість мовлених дій, вчинків та інших зовнішніх проявів мовленої діяльності людини; уміння прогнозувати можливі способи комунікативної поведінки інших людей у контексті тих або інших комунікативних ситуацій; розвиток здатності проектувати доцільні та розумні способи спілкування з іншими людьми, самостійно мислити, усвідомлювати, розуміти та приймати відповідальність за наслідки власної мовленої поведінки; уміння довіряти своїм почуттям i відкрито висловлювати їx. 3 іншого боку, рівень розвитку комунікативної компетентності майбутнього фахівця тісно пов'язаний зі встановленням внутрішнього балансу між інтелектуальною та емоційною сферами діяльності особистісних структур свідомості й розглядається як основний особистісно-розвивальний чинник. Рівень комунікативної компетентності $\epsilon$ важливим для встановлення «я-концепції» майбутнього фахівця, для визначення й усвідомлення особистісної позиції, розкриття особистісного потенціалу студента в навчальній і професійній діяльності (Амонашвили, 1996: 496). Комунікативна компетентність фахівця розглядається як особистісно-соціальна інтегральна якість особистості, що необхідна майбутньому спеціалісту для правильного оцінювання комунікативних ситуацій спілкування, які визначаються особистісними цілями або структурою цілей, правилами соціальної поведінки; системою ролей, характерною для певної комунікативної ситуації (M. Argyle, A. Furnham, J. Graham). Низка сучасних дослідників розглядає процес формування комунікативної компетентності як психосоціальну якість особистості, що визначається як інтегральне особистісне новоутворення, як внутрішня сила й упевненість особистості у виконанні професійних обов'язків, які з'являються від усвідомлення цінності й важливості наявності розвиненої комунікативної спроможності 3 метою ефективної взаємодії із соціальним оточенням та іншими людьми (Л. Х'єлл, Д. Зіглер). Деякі дослідники пов'язують формування комунікативної компетентності безпосередньо 3 умінням надавати соціально-психологічний прогноз будь-якої комунікативної ситуації, визначати напрям, робити прогноз професійної комунікації й розвивати вміння адаптуватися в ній (Е. Руденський). Комунікативна компетентність «передбачає ситуативну адаптивність невербальними та вербальними засобами соціальної поведінки» (Андреева, 1980: 414), уміння швидко й 
адекватно розбиратися в численних і різноманітних комунікативних ситуаціях, опанування ефективною комунікаційною технікою (Кузин, 2002: 320).

Комунікативна компетентність передбачає також насамперед усвідомлення власних потреб і розуміння ціннісних орієнтацій, техніки особистої діяльності, своїх стійких упереджень стосовно різноманітних проблем (перцептивні вміння), бажання сприймати нову інформацію із зовнішнього середовища, своїх можливостей під час розуміння норм і цінностей інших соціальних груп і культур, своїх почуттів і психічних станів у зв'язку з впливом факторів навколишнього світу тощо (Кузин, 2002: 320).

Комунікативна компетентність $є$ змістовим компонентом загальної професійної компетентності особистості, змістово-технологічним елементом системи професійної освіти. Побудова науково обгрунтованої моделі підготовки фахівця 3 маркетингу та іiі оптимальне впровадження у вишах можливе при опорі на адекватну модель компетентного спілкування і знання психологічних основ спілкування й управління.

Отже, комунікативна компетентність майбутніх маркетологів - це комплексна властивість особистості, що характеризується ступенем залучення до комунікативної діяльності й визначає якість цієї діяльності. Комунікативна компетентність у силу своєї комплексності може бути представлена як конструкція, що складається 3 трьох аналітично помітних, загалом же пересічних компонентів, які можна представити у вигляді підконструкцій. Кожен окремий елемент включає систему знань, умінь та особистісних якостей, які відіграють ключову роль як під час реалізації, так i в процесі засвоєння комунікативно-компетентної поведінки.

Структура комунікативної компетентності включає такі компоненти:

1. Когнітивний компонент передбачає вміння, пов'язані 3 рішенням інформаційно-змістових аспектів спілкування; побудовою загальної стратегії взаємодії; сприйняття партнерами один одного.

2. Операційно-діяльнісний компонент передбачає знання мови спілкування; пізнавальних процесів; мовленнєвого етикету, норм спілкування, прийнятих у суспільстві; невербальну поведінку культури.

3. Мотиваційно-ціннісний передбачає такі якості особистості професіонала, як спрямованість; товариськість; потреба в спілкуванні; комунікативні схильності; самооцінка; емпатія.
Ураховуючи специфіку маркетингової діяльності, Г. Андрєєва виокремлює три взаємопов'язані сторони в структурі комунікації (Рубинштейн, 2003: 720):

Комунікативний компонент спілкування 3'являється під час інформаційного обміну, передачі відомостей, планів, вимог тощо. Специфіка інформаційного обміну полягає у взаємодії суб'єктів (спостерігається не тільки інформаційний рух, а й обмін думками, узгодження дій); можливості впливу на поведінку комунікаційного партнера; наявності єдиної чи подібної системи кодування й декодування повідомлень (мовленнєвий аспект: ідентичність лексичної й синтаксичної систем, схоже усвідомлення комунікаційних ситуацій); імовірній появі особливих комунікативних бар'єрів.

Важливо підкреслити, що комунікативна сторона спілкування забезпечує реалізацію маркетингових комунікацій, які виконують інформативну, переконувальну, нагадувальну, заохочувальну функції під час використання реклами, здійснення зв'язків із громадськістю, організації персональних продажів тощо.

Інтерактивна сторона спілкування відображає міжособистісну взаємодію. Інтерактивне спілкування пов'язане з організацією спільної діяльності людей, їхньої взаємодії (інтеракції). За умови групової діяльності учасники не тільки обмінюються інформацією, а й здійснюють спільну діяльність. В економічній галузі основними видами взаємодії $€$ кооперація й конкуренція. Кооперація - вид взаємодії, яка спрямована та сприяє спільній діяльності (опора на взаємодопомогу, співробітництво). Конкуренція - вид взаємодії, в основі якого лежить суперництво, змагання за першість; за сутністю цей вид розхитує спільну діяльність. Під час здійснення професійного спілкування в маркетинговій діяльності інтерактивна сторона спілкування повинна бути орієнтована на кооперацію, тобто в майбутніх фахівців необхідно формувати відповідні інтерактивні вміння та навички.

Перцептивна сторона спілкування пов'язана 3 формуванням у суб'єкта комунікації іншого образа (сприйняття зовнішніх фізичних особливостей, розуміння іiї психологічних рис, особливостей поведінки). У соціальній психології це позначається як «соціальна перцепція» (сприйняття людини людиною) (Андреева, 1980: 414). Перцептивна сторона комунікації не вичерпується лише сприйняттям, а й включає когнітивні процеси: розумові дії, емоції, а також пам'ять. Суб'єкт комунікації намагається уявити думки іншої людини, іiї наміри та переживання, здога- 
датися про взаємини, які мають між собою комуніканти, прагне зрозуміти іншого. Цей процес містить якості особистості суб'єкта комунікації: життєвий досвід, комунікаційні цілі, установки (Андреева, 1980: 414). Розуміння іншого - процес, під час якого спостерігається зображення зовнішніх ознак комунікаційного партнера, співвіднесення особистісних якостей комунікантів, як результат, розуміння внутрішнього світу й поведінки іншої людини. Під час побудови стратегії взаємодії суб'єкту спілкування необхідно враховувати мотиви й установки іншої людини, те, як ця інша людина розуміє власні мотиви й установки. Усвідомлення себе через інших здійснюється через механізм емпатії.

Емпатія - здатність до розуміння почуттів, переживань, станів іншої людини та співпереживання. Важливим $є$ те, що на основі розуміння почуттів, переживань іншої людини партнер по спілкуванню оцінює власні дії та вчинки, які викликали відповідні почуття. I на цій підставі корегує свою поведінку, контролює емоційні прояви, щоб досягти необхідної реакції з боку партнера по спілкуванню. Емпатійність у спілкуванні пов'язана з умінням віднаходити емоційний контакт зі співрозмовниками та налагоджувати відносини взаємної симпатії й довіри, адекватно реагувати на зміни обставин спілкування, перебудовувати спілкування з урахуванням зміни емоційного стану партнерів (Рубинштейн, 2003: 720). У професійному спілкуванні маркетолога емпатія посідає важливе місце, оскільки від уміння викликати необхідні почуття, переживання і стани потенційних покупців (клієнтів) залежить попит та обсяг продажів, а отже, й ефективність маркетингової комунікації.

Важливу групу вмінь, необхідних маркетологу для здійснення ефективного спілкування, становлять уміння професійної взаємодії, які безпосередньо пов'язані зі здійсненням маркетингової діяльності, а саме: вести діалог відповідно до цілей професійної діяльності; дотримання правил етикету; проводити власну презентацію компанії, товару чи послуг; вести конструктивні переговори, результативні ділові бесіди, дискусії; толерантно ставитися до протилежних думок, критично оцінювати нову інформацію; встановлювати й постійно підтримувати необхідні ділові зв'язки із суб'єктами маркетингової діяльності; планувати й організовувати рекламні, інформаційні кампанії; використовувати методики реалізації маркетингових комунікацій; уміння організовувати переговори, підписання документів тощо.
Проаналізувавши роботи науковців у галузі професійної освіти економістів, зміст освітньо-професійної програми підготовки бакалавра за спеціальністю «Маркетинг», виокремлюємо сукупність комунікативних умінь, які $є$ необхідними для формування комунікативної компетентності:

- здійснювання організаційних заходів щодо посилення конкурентних позицій підприємства;

- виконання представницьких функцій служби маркетингу у взаємодії з іншими структурними підрозділами підприємства;

- установлювання контактів, ведення переговорів та укладання угод 3 фірмами-контрагентами необхідних послуг;

- використання інноваційних форм ділового спілкування (виставки, ярмарки й інші заходи закупівельно-торгової та комунікаційної діяльності);

- розв'язування конфліктних ситуацій та інших етичних проблем, які можуть виникати в процесі маркетингової діяльності;

- планування, організація й проводження презентацій проектів або продуктової лінії клієнтської компанії;

- пристосування рекламно-інформаційних матеріалів підприємства до умов ведення бізнесу на внутрішніх і міжнародних ринках;

- готувати маркетингову документацію та звітність;

- дотримуватися етики ділового спілкування;

- здійснювати ефективну комунікаційну взаємодію: чітко, послідовно й логічно висловлювати свої думки та переконання;

- вести конструктивні переговори, ділові бесіди; толерантно ставитися до протилежних думок, брати участь у дискусіях, критично ставитися до нової інформації;

- готувати та проводити презентації й публічні виступи в аудиторіях різного типу; уміння встановлювати ділові контакти 3 різною категорією суб'єктів маркетингової діяльності (споживачами, виробниками, постачальниками, представниками кампаній, посередниками та ін.);

- уміння встановлювати й постійно підтримувати необхідні ділові зв'язки зі споживачами;

- уміння планувати й організовувати рекламні, інформаційні кампанії.

Висновки. Проведений аналіз дослідження проблеми розвитку комунікативної компетентності майбутніх маркетологів у процесі фахової підготовки дав змогу зробити такі висновки: підготовка фахівців з маркетингу значною мірою має економічний характер, спрямована на вивчення різних аспектів організації виробництва, збуту 
товарів і послуг, підвищення попиту покупців, проте формуванню навичок професійного спілкування, розвитку в студентів умінь здійснювати ефективну комунікацію не приділяють належної уваги у вищих навчальних закладах. В основі професійної діяльності маркетолога лежить професійне спілкування, яке є невіддільним і дуже важливим складником маркетингу. Виконання перелічених функцій маркетингових комунікацій свідчить про те, що маркетолог повинен володіти значним обсягом знань, умінь і навичок, пов'язаних із професійною комунікацією, щоб вирішувати такий широкий спектр професійних завдань. Володіння комунікативними вміннями та навичками значною мірою визначає ефективність професійної діяльності маркетолога.

\section{СПИСОК ВИКОРИСТАНИХ ДЖЕРЕЛ}

1. Амонашвили Ш. А. Размышления о гуманной педагогике. Москва : Педагогика, 1996. 496 с.

2. Андреева Г. М. Социальная психология. Москва : МГУ, 1980. 414 с.

3. Емельянов Ю. Н. Активное социально-психологическое обучение. Ленинград, 1985. 165 с.

4. Кузин Ф. А. Культура делового общения : практическое пособие. Москва : Ось-89, 2002. 320 с.

5. Рубинштейн С. Л. Основы общей психологии. Санкт-Петербург : Питер, 2003. 720 с.

\section{REFERENCES}

1. Amonashvili Sh. A. Razmyishleniya o gumannoy pedagogike / Sh.A. Amonashvili. -[ Reflections on humane pedagogy] M.: Pedagogika, 1996. - 496 p. [in Russian].

2. Andreeva G. M. Sotsialnaya psihologiya. [Social Psychology] Moskva : MGU, 1980. 414 p. [in Russian].

3. Emelyanov Yu. N. Aktivnoe sotsialno-psihologicheskoe obuchenie. [Active social and psychological training] L., 1985. - 165 p. [in Russian].

4. Kuzin F. A. Kultura delovogo obscheniya : [Business Communication Culture] prakt. posobie. Moskva : Os-89, 2002. 320 p. [in Russian]. $720 \mathrm{p}$.

5. Rubinshteyn S. L. Osnovyi obschey psihologii. [Fundamentals of General Psychology] Sankt-Peterburg: Piter, 2003. 